\title{
Acculturation and employment dynamics in a Brazilian NGO aimed at Haitian refugees' social integration
}

\author{
EduARDo Estellita de OLIVEIRA SANTOS ${ }^{1}$ \\ DARCY MITIKO MORI HANASHIRO ${ }^{1}$
}

\author{
${ }^{1}$ Universidade Presbiteriana Mackenzie / Programa de Pós-Graduação em AdMinistração de EMpresas, SÃo PaUlo - SP, Brazil
}

\begin{abstract}
Since the earthquake in 2010, over one hundred thousand Haitians have migrated to Brazil. The issue of employment and cultural integration of refugees received intense attention from civil society between the years of 2016 and 2018, a period of economic crisis and double-digit unemployment rates in Brazil. This article aims to understand how the employment and social integration processes were combined into the activities of an NGO that works with Haitian refugees. It also investigates how these activities were adjusted to changing economic circumstances in the host country. We adopted Berry's theoretical approach (Berry, 1997) and explored in depth the activities organized by the NGO: intercultural seminars, conversation circles, Portuguese courses, seminars for employers, mediated job interviews, and company visits after employment. We conducted in-depth interviews with the administrators, non-participant observation of the activities and documental analysis. The data was treated through content analysis (Bardin, 2008), allowing us to capture how the activities were implemented, their goals, and the organizational values that underpinned them. This study expands the literature on refugee integration by presenting the processes of employment and acculturation as inseparable phenomena, that precede or follow one another according to the socioeconomic condition of the host country and the profile of the migratory wave. By adopting the perspective of the NGO administrators, it also provides a practical contribution to legislators and social entrepreneurs who desire to structure programs for refugees that are regular, cohesive and coherent.
\end{abstract}

Keywords: Haitian refugees. Acculturation. Employment. Integration process.

\section{Dinâmicas de aculturação e acesso ao emprego em uma ONG brasileira voltada para a integração social de re- fugiados haitianos}

\section{Resumo}

Desde o terremoto de 2010, mais de cem mil haitianos migraram para o Brasil. A questão do acesso ao emprego e da integração cultural de refugiados recebeu intensa atenção da sociedade civil entre os anos de 2016 e 2018, período de crise econômica e taxas de desemprego de dois dígitos no Brasil. Este artigo tem como objetivo entender como os processos de acesso ao emprego e integração social foram combinados nas atividades de uma ONG que trabalha com refugiados haitianos. Investiga também como essas atividades foram ajustadas diante de mudanças nas condições econômicas no país anfitrião. Adotamos a abordagem teórica de Berry (Berry, 1997) e exploramos em profundidade as atividades organizadas pela ONG: seminários interculturais, rodas de conversa, cursos de português, seminários para empregadores, entrevistas de emprego mediadas e visitas às empresas empregadoras. Realizamos entrevistas em profundidade com administradores, observação não participante das atividades e análise documental. Os dados foram tratados por meio da análise de conteúdo (Bardin, 2008), permitindo capturar como as atividades foram implementadas, seus objetivos e os valores organizacionais que as sustentavam. Este estudo expande a literatura sobre integração de refugiados, apresentando os processos de acesso ao emprego e aculturação como fenômenos inseparáveis, que se precedem ou se seguem de acordo com a condição socioeconômica do país anfitrião e o perfil da onda migratória. Ao adotar a perspectiva dos administradores da ONG, também oferece uma contribuição prática para legisladores e empreendedores sociais que desejam estruturar programas regulares, coesos e coerentes para refugiados.

Palavras-chave: Refugiados haitianos. Aculturação. Emprego. Processo de integração.

\section{Dinámica de aculturación y acceso al empleo en una ONG brasileña dedicada a la integración social de los refugiados haitianos}

\section{Resumen}

Desde el terremoto de 2010, más de cien mil haitianos han emigrado a Brasil. El tema del acceso al empleo y la integración cultural de los refugiados recibió una intensa atención de la sociedad civil entre los años 2016 y 2018, un período de crisis económica y tasas de desempleo de dos dígitos en Brasil. Este artículo tiene como objetivo comprender cómo se combinaron estos procesos en las actividades de una ONG que trabaja con refugiados haitianos. También investiga cómo se han ajustado estas actividades ante los cambios en las condiciones económicas del país anfitrión. Adoptamos el enfoque teórico de Berry (Berry, 1997) y exploramos en profundidad las actividades organizadas por la ONG: seminarios interculturales, círculos de conversación, cursos de portugués, seminarios para empleadores, entrevistas de trabajo mediadas y visitas a empleadores. Realizamos entrevistas en profundidad con administradores, observación no participante de actividades y análisis documental. Los datos se trataron mediante análisis de contenido (Bardin, 2008), lo que permitió capturar cómo se implementaron las actividades, sus objetivos y los valores organizacionales que las respaldaban. Este estudio amplía la literatura sobre la integración de refugiados, presentando los procesos de acceso al empleo y la aculturación como fenómenos inseparables, que preceden o siguen según la condición socioeconómica del país de acogida y el perfil de la ola migratoria. Al adoptar la perspectiva de los administradores de la ONG, también ofrece una contribución práctica para legisladores y emprendedores sociales que desean estructurar programas regulares, cohesivos y coherentes para los refugiados.

Palabras clave: Refugiados haitianos. Aculturación. Empleo. Proceso de integración. 


\section{INTRODUCTION}

In order to escape unemployment and political instability in their home country (Audebert, 2017; Pachi, 2019; Peres, 2015) over 100,000 Haitians have migrated to Brazil since the earthquake in January 2010 (Cavalcanti, Oliveira \& Macedo, 2019). Haiti is the nation with the second largest amount of refugee requests in Brazil, contributing to $10 \%$ of the total requests in the last decade. During the year of 2014 alone, the country received 16,779 refugee requests from Haitian nationals (Ministério da Justiça e Segurança Pública, 2019).

The matters of refugees' access to employment and their social integration in the local community have received sustained attention from civil society and the media. The recent migrating waves of Haitians, Syrians and Venezuelans have rekindled the debate in Brazilian society as well, partly due to the profound political and economic crisis that struck the country and unemployment rates reaching $13 \%$ (Abdala, 2018). On the one hand, the economic climate has favored the rise of incidents of racism and xenophobia. On the other hand, the sharing of images, on conventional and social medias, depicting the humanitarian crisis in the refugees' homeland and the conditions of their journeys has encouraged different sectors of civil society to consider their role in the welcoming of these people.

In the city of São Paulo, at least seven NGOs work directly with refugees. This study was conducted in one such NGO, from now on referred as NGO New Life, a fictitious name selected to preserve anonymity. NGO New Life is situated in the city's downtown area and has received migrants for the past 44 years. Promoting access to employment for migrants is a central aspect of its work. During the first half of the year of 2015, it has received, beside migrants from other nations, 620 Haitians, which amounts to approximately $7 \%$ of the total of Haitians that have entered the country in the period ${ }^{1}$. Their presence invites to reflect on the challenges of social integration when two cultures meet and of access to the local job market.

Despite the social and economic relevance of the theme, our research in international databases has identified a scarcity of articles addressing simultaneously acculturation activities for refugees and initiatives aimed at promoting access to formal employment, essential elements to their survival and thriving in the host community. The understanding of this phenomenon presents itself as a relevant research theme in Organizational Studies, considering the intensification of migratory waves in contemporaneity. In light of this important gap, we have defined our research problem as follows: Which regular formal activities at the NGO promote the acculturation and access to employment of Haitian refugees and how do these activities evolve in order to adapt to the socioeconomic circumstances of the host country?

By regular formal activities, we mean the group of events organized by the NGO New Life for the refugees, which will be further explored in the field research.

The research's main goal is to identify which activities the NGO New Life offers in order to contribute to the social integration of Haitian refugees. The specific goals are (1) identify the individual, experiential and cultural factors of Haitians that influence in their process of social integration, from the perspective of the NGO administrators; (2) characterize the activities developed at the NGO New Life, prior to and after employment.

Aside from this introduction, the article is divided into four topics: theoretical underpinnings, method, results and discussion, and conclusions.

\section{THEORETICAL UNDERPINNINGS}

We conducted a literature review in April 2018 in the EBSCO and SciELO (Scientific Electronic Library Online) databases, of full articles published in academic journals, in Portuguese or English languages, for the period between 2002 and 2018.

We used the combination of keywords in Portuguese language aculturação (acculturation) AND refugiado (refugee), aculturação (acculturation) AND migrante (migrant), trabalho (employment) AND refugiado (refugee). These combinations did not return a result, so we selected articles with any of the three keywords: refugee, Haitian or acculturation. After reading the summary

${ }^{1}$ On November 11th, 2015, the Brazilian government has granted 41.632 Haitians a permanent visa. This measure was taken to expedite their pending migratory status. Although it is unclear how many of these had moved to the country in 2015, official sources claim most of the people benefited from the measure were already in Brazil since 2010 (Cavalcanti, Tonhati, Dutra \& Oliveira, 2017). Cross-referencing data from frontier movement, asylum requests (Cavalcanti et al., 2019) and work permits (Cavalcanti, Oliveira \& Araujo, 2016) we were able to estimate that approximately 9.000 Haitians moved to Brazil during the first semester of 2015 
of the sixteen articles obtained, only two discussed employment: a bibliometric review of studies on the influence of migrant entrepreneurship in the social integration process (Cruz \& Falcão, 2016) and a comparative study of employment status between students from Cape Verde and Haiti (Pongnon, 2016).

In order to expand the theoretical framework, we applied the same criteria with any of the same three keywords in English, obtaining 95 articles. Only six of them addressed refugee acculturation and employment and two presented relevant contributions: one on the role that refugee social networks in Germany play on helping them obtain the first employment (Eisnecker \& Schacht, 2016) and another on refugee employment policies in the United Kingdom (Dhudwar, 2004). No article combined all three keywords.

We sought other relevant studies in the references of the selected articles. Thus, we found studies on the influence of local media consumption on the acculturation process (Alencar \& Deuze, 2017) on the influence of individual values on the acculturation of immigrants in the local work environment (Taras, Rowney \& Steel, 2013) and on the disconnect between the individual acculturation strategies preferences and national policies that reduce refugee options and make integration more difficult (Phillimore, 2011).

The review indicated a gap in national and international literature regarding the interaction between refugee acculturation and access to formal work. Besides that, as pointed out by Berry, (1997) very few of these studies had been conducted in Asia, Africa or South America, where most acculturation takes place.

The National Committee for Refugees (Ministério da Justiça e Segurança Pública, 2019) defines refugee as:

"a person who leaves his country of origin or habitual residence due to a well-founded fear of persecution for reasons of race, religion, nationality, social group or political opinions, as well as due to the serious and widespread violation of human rights, and who cannot or does not want to embrace the protection of that country".

Since 2010, of all Haitian asylum seekers, only one has obtained refugee status (Ministério da Justiça, 2018). However, over 58,000 of them have obtained a humanitarian visa (Ministério da Justiça e Segurança Pública, 2019), which grants them the same rights as the refugee visa: permission to work and access to social services (Audebert, 2017). We will use the term refugee to address the Haitian group, since the stress associated with leaving the country, the high costs and risks of the journey and the permission to work in Brazil puts them in an economic and psychological situation similar to other migrants seeking refuge in the country.

Redfield, Linton and Herskovits (1936, p. 149) define acculturation as "phenomena which result when groups of individuals having different cultures come into continuous first-hand contact with subsequent changes in the original culture patterns of either or both groups". Berry (1997) argues that, in practice, there is an imbalance of power between host society and newcomers, forcing the latter to experience more changes.

In that sense, the process of acculturation raises two main concerns for both members of the dominant (i.e., host society) and non-dominant (i.e., refugees) cultural groups: 1) maintenance of the cultural identity of the non-dominant group and 2) contact and participation of the non-dominant group in the larger society. These issues lead to four possible acculturation strategies, though not all might be available due to the imbalance of power between the cultural groups.

The strategy of Assimilation is in place when the refugee seeks new relationships in the host society in detriment of the maintenance of his culture of origin. Inversely, Separation or Segregation occurs when the refugee values holding on to his culture and avoids contact with the host culture. When there is little interest or possibility for maintaining the culture of origin and the refugee does not wish to establish relations in the host culture, often due to exclusion and discrimination, then Marginalization is in place. Finally, when there's a mutual accommodation between the cultural groups in such a way that the refugee feels encouraged to maintain his cultural identity while participating actively in larger society, Integration occurs. It has been shown that the latter is the most beneficial for the health of the non-dominant group and the larger society (Krishnan \& Berry, 1992; Sam \& Berry, 1995; Schmitz, 1992). Figure 1 presents the relationship between the two main concerns of dominant and non-dominant groups and the four acculturations strategies that ensue. 
Figure 1

\section{Acculturation strategies}

\begin{tabular}{|c|c|c|c|}
\hline & \multirow{2}{*}{\multicolumn{2}{|c|}{$\begin{array}{l}\text { Is it considered to be of value to maintain } \\
\text { one's identity and characteristics? }\end{array}$}} \\
\hline & & & \\
\hline & & YES & NO \\
\hline \multirow{2}{*}{$\begin{array}{l}\text { Is it considered to be of value to maintain } \\
\text { relationships with larger society? }\end{array}$} & YES & Integration & Assimilation \\
\hline & NO & $\begin{array}{l}\text { Separation/ } \\
\text { Segregation }\end{array}$ & Marginalization \\
\hline
\end{tabular}

Source: Berry (1997).

Berry (1997) highlights that age, gender, education and cultural distance act as moderating factors prior to acculturation. Once in the host country, experiences with prejudice and discrimination, support by social services, access to public health and education, and the permission to work function as moderating factors during acculturation. Phillimore (2011) builds on Berry's acculturation framework and identifies how individual, cultural and experiential factors (i.e., relating to the traumatic experience of forced migration) combine to influence the acculturation strategy available to the non-dominant groups in the United Kingdom. The difficulty for the refugee to adopt an integration strategy depends on a series of factors both in the country of origin, such as political and economic context, death of family members or events that trigger post-traumatic stress disorder, and in the host country, such as restrictive labor laws for migrants, separation from fellow countrymen and discrimination suffered. These factors are often beyond the will of the refugee, justifying the importance of public policies that promote professional insertion, participation in the local culture and the valuing of the refugees' cultural identity.

In that sense, Aycan and Berry (1996) have identified that unemployment and underemployment had implications over the acculturation of Turkish migrants in Canada. Not only did work provided access to financial resources that allow for more active participation in society, it also offered purpose to life, psychological well-being, and the establishment of daily contact with members of the dominant society, thus facilitating the acquisition of skills to navigate the new social environment. The authors identified a U-shaped curve in the Turkish migrants social integration process, which begins with a status inconsistence on their first occupation in the host country, in comparison to their previous situation in the country of origin, that, over time, tends to be reduced.

The intensification of the Latin American route as part of the Haitian diaspora over the last decade is the result of a combination of factors: the lack of work, career perspectives and good living conditions in the country of origin, restrictions to Haitian immigration to North America and France, the Brazilian coordination of the United Nations Stabilisation Mission in Haiti (MINUSTAH) and the "Humanitarian Visa" coupled with the work permit granted by the Brazilian government. In this context, Brazil became an attractive settlement or transit destination towards Chile or Argentina (Cavalcanti et al., 2017).

During the development boom in preparation for the World Cup and Olympic Games in Brazil, Haitian refugees have been mainly absorbed by the following sectors: construction, poultry and meat slaughtering and processing, restaurants and bars, housekeeping and cleaning (Audebert, 2017; Cavalcanti et al., 2016).

Over the decade, more than $90 \%$ of refugees and asylum seekers from all nations have worked in Brazil for over 44 hours per week for 1.5 times the minimum wage: an amount 33\% below the national average. Among all nations, Haitian refugees had the lowest starting average earnings in 2018 (44\% below the national average), making them particularly vulnerable to work precariousness and exploitation (Cavalcanti et al., 2019; Pachi, 2019).

Pongnon's (2016) comparative study carried out in Brazil among university students from Haiti and Cape Verde identified that, despite both migrants suffering from racism and discrimination, Haitians had encountered more challenges in acculturating in Brazil due to language barrier and lesser institutional support in the recognition of their diplomas. On the other hand, Cape Verde migrants, being from a Portuguese-speaking country, benefited from a simpler process of diploma validation. Combined, these factors resulted in the orientation toward and maintenance of Haitians in a situation of underemployment. 
As a result, Cavalcanti et al. (2019, p. 147) couldn't obtain accounts of Haitian refugees having experienced the U-shaped curve in their work status. Instead, as the employment crisis intensified in Brazil, several Haitian refugees expressed concerns about professional stagnation in a L-shaped curve, loss of buying power and started considering alternative routes towards Southern California.

As will be discussed in the results section, the activities carried out by the NGO New Life aim to promote acculturation and access to employment, mitigating some of the moderating factors prior to and during acculturation (Berry, 1997; Phillimore, 2011) that impact negatively on their social integration to the Brazilian society.

\section{METHOD}

In order to explore the complex relationship between the social phenomena of Haitian refugees' employment access and acculturation, we opted for the qualitative research approach (Creswell, 2010). We pursued multiple methods of investigation (non-participant observation of the activities, documental analysis and unstructured interviews with the administrators) in order to apprehend the emerging aspects of the research, we alternated stages of data collection and data analysis in a circular manner and combined different sources in a coherent and holistic interpretation of the phenomenon.

The reason for the choice of the Haitians among other nationalities represented in the NGO is due to 1) the continued representativeness of Haiti in the total of annual requests for asylum in Brazil; 2) the expressive number of Haitians served by the NGO New Life, in comparison to the overall number of Haitians seeking asylum in Brazil during the last decade; 3) the additional acculturation challenges encountered by these people, due to the language barrier (Pongnon, 2016); 4) the proximity of the first author of the article to this refugee group through his intervention in the intercultural seminars within the NGO New Life.

Since the first author works as a volunteer in the intercultural seminars, we have decided not to include them as subjects of the research to avoid bias in the responses or sentiments of undue pressure. Furthermore, since most of the participants of the seminars have recently arrived in the country, do not speak the language and do not know the Brazilian culture, it would be unlikely that they could accurately assess their level of acculturation at that moment. In turn, the NGO administrators can present their intentions and the results of the activities carried out, acting as a bridge between the institution, Haitian refugees, and the hiring companies.

The interviews took place in May 2018, with three administrators of the NGO New Life: the Work Hub Coordinator (E1), the NGO's Communications Coordinator (E2) and the Citizenship and Education Hub Coordinator (E3). They were selected due to the central role they play in structuring and continually improving the employment access activities for refugees (E1), in monitoring the adaptation of refugees to employment in Brazil (E1), in raising cultural awareness among employers and volunteers (E1, E2 and E3), in the implementation of the Portuguese language program (E3) and in building partnerships with public and private sectors to offer academic and professional education to the refugees (E2 and E3). For these reasons, the interviewees were the best positioned to clarify how the activities aimed at acculturation and employment occur at the NGO.

Due to the reduced structure of the NGO staff and the consistency identified in the statements, it was not necessary to conduct subsequent interviews with other members of the organization. The interviews lasted on average 50 minutes, were recorded with the authorization of the participants and later transcribed literally. In addition to the interviews, we have conducted documental analysis and non-participant observation in some of the activities of the NGO, such as the intercultural seminar, the seminar for employers, the mediated job interview and the company visit. All these contents were categorized into three dimensions: knowledge, skills and attitudes required of the different agents (refugees, volunteers and employers) in order to improve social integration in the work environment. The documental analysis also consisted of the managerial reports, Portuguese course booklet and slides from the seminar presentations. This material was authorized to be used for academic purposes.

The material collected during the interviews and non-participant observation activities was submitted to qualitative perspective of content analysis (Bardin, 2008). To understand the latent content of the message contained in the interviews and to offer a scientific treatment to the data, this method is divided into pre-analysis, exploration of the material and 
treatment of the results (Bardin, 2008). In the pre-analysis phase, the transcription of the recorded interviews and the floating reading of the material was carried out. In the exploration phase, information was organized into analysis codes and categories. In the treatment of the results phase, a relevant meaning to the research was inferred through the circular process, that is, the interviews were conducted spaced from one another in order to analyze and restructure the questions according to emerging categories.

\section{RESULTS AND DISCUSSION}

From the non-participant observations, documental analysis and unstructured interviews, we have identified six categories concerning the process of acculturation and employment access of Haitian refugees.

Regarding first specific goal and based on Phillimore's work (2011), we identified three categories: individual factors, experiential factors, cultural factors. Regarding the second specific goal, we found three categories: guiding values, activities offered and intended outcomes.

Even though the NGO administrators have had prolonged contact with a significant number of Haitians over the years, it is important to note that the individual, experiential and cultural factors identified in the research reflect their perceptions and not necessarily the reality. This fact was intentional in the research design, as their perceptions influence which activities are offered and their desired outcomes.

Among the individual factors, a relationship between education level and linguistic challenges in acculturation was reported. This link occurs because, in Haiti, individuals with a lower education level communicate exclusively in Creole, making daily communication and learning the Portuguese language more difficult. This assertion during the interviews has been verified during the non-participant observation activities of the intercultural seminar in French and Portuguese, the mediated job interview and the company visit. In general, the refugees that spoke French as well as Creole experienced a faster adaptation to the Portuguese language. On the other hand, those with a degree in higher education also face challenges associated with the cost and long wait for a diploma revalidation in Brazil, forcing them to underemployment.

Finally, individuals of African-origin religion, such as voodoo, suffer from more prejudice and find it more difficult to acculturate in Brazilian society, due to the association that Brazilians make of their religion with "demonic practices", as pointed out by E2:

I had the impression that those who had more access to school, spoke French and had a Christian religion, found it easier to integrate into society [...] I myself took on the role of giving a lecture commenting on the voodoo religion. What were the traditions like? Because we shouldn't see it as a "religion of the devil", almost a colonialist view on our part (E2).

Among the experiential characteristics, anxiety and agitation were the words frequently used to describe the state of many upon arrival at the NGO. These behaviors are part of the context of experiences with deaths of family members and a crossing to São Paulo often fraught with dangers and human exploitation. In order to survive, many have developed defense mechanisms that need to be gradually relaxed, so that the integration process takes place. The contact with other nationalities in the NGO housing accommodations and the lack of job offers due to the economic crisis are other factors that hinder the acculturation process and success of employment. The NGO administrators feel therefore responsible for providing medical and psychological support in cases of post-traumatic stress disorder and establishing an environment of trust, transparency, and equanimity.

During the interviews, it was evident that the NGO administrators had a positive outlook on Haitian culture, characterized by descriptions that emphasize allegedly cultural characteristics such as politeness, honesty, commitment, effort, joy and a sense of gratitude. This gratitude is described by E1: "He [Haitian] is grateful to HR, to the people in the company, to a colleague he made. He has something of gratitude to all of that and sometimes he says it very discreetly. It doesn't have a "suck up" aspect, it's real gratitude, with a teary eye" (E1).

The meaning of work for the Haitians was a recurring theme in the interviews, described as the engine behind many of their observed behaviors. Even if for all migrants finding a job is the main path to start rebuilding a life in the host country, the 
statements of E1 and E2 indicate a belief that the meaning of work is a cultural factor that guides Haitian refugee's behavior and supports their access and maintenance in employment. "He believes that work is life, dignity, freedom, evolution, improvement. He [Haitian] believes that through work, the whole thing will happen in his life" (E1); "[The Haitian says] "I go to work sick; I have a commitment. I will go because I know that if I miss, my machine will not work" (E1); "They all said "No, I can do any job, I will learn, I will work hard ". I hear that a lot in their speech" (E2).

Work takes on another instrumental significance for Haitian refugees. It is through work that they can send money to their family, offer them a better quality of life in Haiti or bring them to Brazil. From this perspective, work allows for integration to occur, as described by Berry (1997), the maintenance of cultural and family ties while promoting contact with people from the dominant culture. The Haitian refugees, especially the young men, fear that family members will interpret a delay in sending money as an abandonment. While recognizing the work exploitation that several Haitians experience in the Brazilian job market, E1 reflects on the anxiety, the sense of urgency and the sense of fulfillment expressed by them:

Even though he is not very happy [with the low wages] [...] he managed to stabilize himself minimally. He managed to reorganize his life. Many times, he has already managed to bring his wife or son or is sending them money. "I came here to be able to work and send money for my son to study. That was my goal!" Then he shows me some photos of a house that his family was able to build in Haiti with the money that he earned here "Look at how it looks!" (E1).

The NGO New Life has developed a wide array of activities for refugees in order to promote their social integration in Brazil. Among these activities, we highlight the housing accommodations for the newly arrived, social services and psychological support, assistance with paperwork, Portuguese courses for non-Portuguese speakers, intercultural seminars, partnerships with professional courses, celebrations of the culture of origin and mediated job interviews. Before presenting in further detail the activities carried out by the Work Hub, or in partnership with it, it is important to describe the values that guide the NGO's administrators. Understanding these values makes it possible to discern the logic behind the structure and the format of interaction with different agents in its ecosystem (refugees, employers, volunteers, media and government agencies).

From the administrators' testimonies, we could identify several values. References to protagonism, dignity, dynamism and relationship building were frequent in all interviews, suggesting they were shared.

The guiding value behind most of the NGO's activities, mentioned by all respondents, was protagonism, as observed in the statements below:

All the activities that take place here at the Work Hub, throughout the NGO, have only one objective: the refugee's protagonism. That is the main goal. It is giving him the conditions to stand on his own (E1).

I was like, "Wow, they are just so unfortunate!" By doing so, I took away their agency. And now that I work here for all these years, I give this agency back to them. I say "They are human beings. They are fully capable of reshaping their lives, no matter how much they had been at risk, as was the case with Haitians" (E2).

The value of dignity appeared on the analysis on several occasions as well, being exemplified by E1 as follows:

There is one migrant who once when the queue ended in his turn, he kneeled down and said "Please!" [In a tearful, begging tone]. We don't allow this ... How are you going to get the job? Are you going to weep your way into the job? What clothes do you put on? With shaggy hair? As if you were heading to the bakery or wherever? No, we get organized to get the job. We get ready (E1).

The value of dynamism appeared implicitly during the interviews and explicitly in the number of versions of the seminar slide decks and Portuguese course handouts. The teams are proud of their capacity for innovation and their ability to rapidly reorganize themselves in the face of significant changes in migratory flows. According to E1, "each migratory flow has a profile, and we adapt the degree, the level, the time, everything that is done, at that moment". 
Finally, the value of relationship building accounts for the format of most of the activities promoted by the NGO New Life and the Work Hub. The NGO's uniqueness comes from its ability to organize a meeting of humans, instead of acting as a mere agency that forwards curricula and job offers.

There is no point in looking for the person in the file or in offering to the employer when he arrives: "I will present you some resumes." No, here the concept is humans meeting. It is at the meeting that it all happens. We promote meetings and mediate these meetings. There are the intercultural meetings, with the employer and with the refugee, there is the meeting during the job interview and the hiring. Then there is the company visit, and many other meetings, like when they come here on vacation or on their day off. Or when they managed to bring their wife or children to Brazil and come to introduce them to us (E1).

Guided by these values, the Work Hub offers, at its premises, six formal activities for promoting the refugees' acculturation and employment: intercultural seminar, conversation circles, Portuguese course for non-Portuguese-speaking refugees, seminar for employers, mediated job interviews and company visits.

The intercultural seminar takes place weekly, for two hours. Organized in partnership with interculturalist volunteers, the seminar is offered in four languages and is intended mainly for newcomers. It is a mandatory activity for all of those who wish to participate in the mediated job interviews. The intercultural seminar aims to share information about culture shock and the stages of intercultural adjustment (Black, Mendenhall \& Oddou, 1991). In addition, the seminar provides guidance for job interviews, informs about other activities offered at the NGO and introduces important aspects of Brazilian culture that will have a direct impact in their social integration, such as personalism, informality and veiled racism.

In order to deal with the challenges and frustrations of looking for work during the economic downturn and cope with the mood swings associated with the acculturation process, the conversation circles were created in 2016. It offers them a safe space for sharing, while encouraging them to persevere as protagonists of their job search.

Sometimes, the person gets into a frequency of despair or anxiety, in which it seems that nothing is going anywhere. As much as he swims, it seems that nothing happens. Swim and die on the beach. The conversation circle brings this possibility that the person can express this, but also with a direction towards an awakening. "What are you doing? You've been here for a year and a half and still can't express yourself in Portuguese, what's going on? What are the resistances? What is not flowing?" (E1).

This space is important for the refugee because both family members in the country of origin and individuals from the dominant culture may be unaware of the challenges associated with migration, which increases their feeling of isolation.

The Portuguese course was incipiently implemented in late 2013, during the Haitian immigration boom and briefly after, it was discontinued. At the end of 2017, it was relaunched by a teacher who had developed an andragogical program based on the values of protagonism and emancipation. Under the responsibility of the Citizenship and Education Hub, the Portuguese course is divided into two simultaneous modules of 25 daily classes of three hours. Each module attracts on average thirty students, but it has a high dropout rate, since participants often leave the program when they find work, due to conflicting schedules. The program employs 20 volunteer teachers. Before leading the classes, they must go through an integration seminar that raises awareness to the refugee's reality and ensures team alignment.

The program is not focused on language proficiency, but on improving communication ease, vocabulary and key grammar elements that are useful in everyday life and at work. Despite claiming a distinct methodological approach, the analysis of the course booklet did not reveal a significant element that sets it apart from other language courses. Our hypothesis is that the high demand for the course within the NGO New Life is a reflection less of its content than of the trust built within the refugee community.

In addition to expanding the employability of Haitian refugees through the improvement of their ability to communicate in the host language, the course allows the administrators to identify remedial actions for individuals with learning disabilities and informally assess language proficiency for referrals to professional courses at the Hub's partners or at state-run educational programs for young adults. 
After a telephone screening of potential employers, the employer seminar aims to raise awareness about immigration, about the refugees' needs for healthy labor relations, and to demystify the recruitment of foreigners. E1 reinforces the need to "understand this HR, I want to know who is going to deal with all this. What is the vision of this company? It can be a tiny family business and people be happy there".

The two-hour program balances a broad presentation on immigration and cultural differences with the practical aspects of hiring (employment contract, expected minimum wage, food and transportation benefits, among others) and the mediated job interview process at the NGO. Taking place twice a week, the goal of the seminar is to verify the real intentions and attitudes of employers and to clarify the interests of refugees, so that the mediated job interviews generate long-term working relationships.

The mediated job interviews involve short job interviews, accompanied by a mediator-interpreter. With approximately 20 candidates, the whole process takes an average of two hours and is followed by the signature of a document formalizing the commitment to ethical working relations between the employer and the selected candidate.

In the end, with the person who is going to sign the term of ethical conduct, we make sure everything is smooth. In the interview, it's the "Can you do this? Do you know how to do that?" We ask the employer not to make the interviews go on for too long and avoid asking questions that would lead them into that place of sensationalism, of sensations: "Oh, how did you get here? Where are your children?" The person starts crying and that's it, the interview is over (E1).

In this process, the mediator takes on a central role, offering a trained look and support to the refugee. He accompanies him during the interview and during the signing of the term of conduct; he verifies that the refugee has all the resources to reach his destination on the first day of work, formalizes and clarifies the job proposal, provides guidance on the level of Portuguese required for the position, acts as a translator and checks whether the proposal presented by the employer during the interview is the same that had been presented to the NGO administration. As expressed by $\mathrm{E1}$, "He is the eyes of the NGO, to see if the job offer is really worthy or not. The mediator needs to have resilience, flexibility, expertise, in addition to speaking one, two, three, or more languages".

The NGO's administrators also conduct weekly visits to the companies where the refugees are employed, to mediate eventual conflicts and to assess the evolution of the job performance and the quality of the relations between the refugee, his employers, co-workers and HR, through a series of individual or group interviews. These visits, announced during the seminar for employers, can take place from the fourth month after hiring, by request of the employer, of the refugee or by probabilistic sampling. Approximately $10 \%$ to $15 \%$ of the companies that have hired refugees at the NGO New Life are visited. In all cases, the visit is pre-scheduled with the HR department and the company's management in order to minimize the impact of the visit on the organization's operations.

The interview with the refugee aims to assess his level of integration in the new community, job satisfaction and stability. It explores how the adaptation to the chosen community took place, what his activities during his time-off are, if he feels recognized and respected at work, if he's been able to send money to his family and if his relationships with colleagues are friendly. As exemplified by E1, the refugee is not always well integrated into the company, which reveals the importance of this post-employment monitoring: "HR wants the refugee to sign a written warning because he doesn't want to have lunch at the cafeteria. "But why don't you want to have lunch at the cafeteria?" "Because the woman who serves the food doesn't like me. She gives me stale food and when I eat it, I get sick." We go there to mediate that".

According to the NGO administrators, the company visit closes off a cycle, consolidates and legitimates the work carried out. It considers the fact that integration does not occur as an immediate consequence of being hired for a job, but as a result of work stability. As E1 comments, "If you are not going to meet the refugee's needs, [then] there is no point that he gets hired and in two months, he's back here."

It is not enough for the NGO New Life to offer activities that promote acculturation and access to employment; it is vital that the companies who hire adopt attitudes and behaviors that favor the permanence of the refugee in employment and the construction of a dignified and mutually beneficial working relationships, free from prejudice, discrimination and exploitation, 
as explained by E1, "Unfortunately, we receive more complaints about companies than about refugees. When the company complains about the refugee, it is more cultural, a Brazilian resistance, such as: "I have always done so. I've always treated my employees like that. Now, why should I have to do it differently for this one?"

The documental analysis of management reports at the NGO New Life attest the influence of the activities offered over the professional insertion of refugees, Haitians and other nationalities alike. During the period between 2012 to 2017, out of the 14,801 refugees registered in the Labor Hub, 6,603 were hired (44.6\%). During the years of the greatest influx of Haitian immigration (2013 to 2015), the hiring rate exceeded 50\%, with access to employment occurring on average, two to three weeks after registration. By 2016, the amount of job offers had decreased by $75 \%$. If during the first years of the modern Haitian diaspora and economic growth in Brazil, many Haitians were able to find and maintain formal employment despite being unable to communicate adequately in Portuguese, with the economic downturn, employers began demanding a more thorough acculturation, which delayed the average length of time before their first formal employment.

In the face of changing circumstances, the NGO New Life managed to adapt by restricting access to the mediated job interviews to refugees with less than a year on Brazilian soil and by inquiring past employers about open vacancies. In less than a year, the NGO managed to reestablish a $27.5 \%$ hiring rate per registered refugee, without suffering a reduction in the quality of offers or in the seriousness of the employer's intentions.

Under the new context, the introduction of new activities focusing on acculturation prior to employment, such as the Portuguese course and the conversation circle, helped to keep Haitian refugees active and protagonists of their social insertion. By focusing on the activities that accelerate their acculturation, the NGO New Life prepared them to become more competitive for the scarcer employment opportunities, inside and outside their walls.

Figure 2 summarizes the intended outcomes and focus of the six formal activities promoted at the NGO's Work Hub.

Figure 2

Summary of outcomes and focus of the formal activities

\begin{tabular}{|c|c|c|}
\hline Activity & Intended Outcomes & Focus \\
\hline $\begin{array}{l}\text { Intercultural } \\
\text { seminar }\end{array}$ & $\begin{array}{l}\text { - Inform and prepare migrants for the acculturation phases } \\
\text { - Present immediately relevant aspects of Brazilian culture } \\
\text { - Manage stress and expectations about job offers } \\
\text { - Provide orientation for job interviews (to reduce anxiety) }\end{array}$ & $\begin{array}{l}\text { Acculturation prior } \\
\text { to employment }\end{array}$ \\
\hline $\begin{array}{l}\text { Conversation } \\
\text { circle }\end{array}$ & $\begin{array}{l}\text { - Offer a safe space for sharing frustrations and encourage protagonism in } \\
\text { the work search and acculturation process }\end{array}$ & $\begin{array}{l}\text { Acculturation prior } \\
\text { to employment }\end{array}$ \\
\hline $\begin{array}{l}\text { Portuguese } \\
\text { course }\end{array}$ & $\begin{array}{l}\text { - Improve communication in Portuguese and build vocabulary that is useful } \\
\text { in everyday life and work } \\
\text { - Identify language skills for professionalizing courses and Adult Education } \\
\text { opportunities }\end{array}$ & $\begin{array}{l}\text { Acculturation prior } \\
\text { to employment }\end{array}$ \\
\hline $\begin{array}{l}\text { Employer } \\
\text { seminar }\end{array}$ & $\begin{array}{l}\text { - Sensitize employers to the refugee's challenges } \\
\text { - Clarify the interests of refugees in finding stable work } \\
\text { - Verify the reasons for hiring refugees (and prevent abuse) } \\
\text { - Share practical information about recruitment of refugees }\end{array}$ & $\begin{array}{l}\text { Acculturation after } \\
\text { employment }\end{array}$ \\
\hline $\begin{array}{l}\text { Mediated job } \\
\text { interview }\end{array}$ & $\begin{array}{l}\text { - Mediate, clarify and formalize employment opportunities } \\
\text { - Offer a convenient and safe place for employers and refugees to meet, } \\
\text { with equal opportunities to all refugees }\end{array}$ & Employment \\
\hline Company visit & $\begin{array}{l}\text { - Evaluate the level of acculturation in the new community, job stability and } \\
\text { mediate conflicts in the workplace } \\
\text { - Consolidate, adapt and legitimate the work done }\end{array}$ & $\begin{array}{l}\text { Acculturation after } \\
\text { employment }\end{array}$ \\
\hline
\end{tabular}

Source: Data from field research. 


\section{CONCLUSIONS}

The present research identified, from the perspective of the NGO New Life administrators, factors that influence the social integration of Haitian refugees in Brazilian society. Moreover, it characterized the six formal activities offered at the NGO, the four values that underpinned them and their contributions, individually and in combination, both for the processes of acculturation and access to work. Through the exploration of the points of interaction between these two constructs, we have obtained a deeper understanding of the challenges of social integration, especially under declining socioeconomic conditions in the host country.

The integration of individuals from another culture in a host community depends on a variety of sociocultural factors, such as cultural distance, language and economic opportunities. When individuals migrate in a situation of vulnerability, these factors are compounded by experiential factors, public opinion, government policies, labor laws, access to health and education, among others.

In recent years, Brazil has made progress in offering refugees' access to work, health, and education. From the legal perspective, refugees have nearly the same rights and obligations as Brazilian citizens and should not encounter administrative barriers to obtain employment. These conditions offer initial opportunities; however, they are insufficient to ensure cultural and social integration. Organizations, like the one presented in this research, exist to fill the gaps so that integration takes place in practice.

This article opens new perspectives for the study of the social integration by treating the processes of professional insertion and acculturation as complementary and inseparable. They do not occur in a set order, and in some cases, access to employment may precede acculturation or even the most basic command of the host nation's language. In this sense, the findings of the research allow us to advance knowledge about acculturation, by shedding light on factors that are still little highlighted in the literature (Berry, 1997). Furthermore, the example of the NGO New Life allows us to understand how these processes may evolve according to the socioeconomic situation of the host country, demanding different solutions from administrators.

The practical contribution of the research lies in the dissemination of how the NGO has articulated its resources to involve employees, volunteers, employers, partners and civil society and has designed learning and mediation activities that are regular, adaptable and coherent. It offers an invaluable model for social entrepreneurs and public servants who wish to structure programs for the refugee community.

Although the understanding of the activities developed at the NGO is relevant, the focus on the administrators' perspectives was a limitation of this study. Future research should include, in the participant's pool, Haitians living in Brazil for two years or longer, their coworkers and employers. Due to the short period elapsed between the first effects of the economic crisis and the field research, we have encountered difficulties finding participants in their work environment that simultaneously had had contact with the new activities introduced at the NGO in response to the crisis and could look back on their social integration. We recognize that they would provide valuable knowledge on the later stages of the acculturation process.

Future research may also explore the dynamics between acculturation and access to employment for other refugee communities. Issues surrounding the influence of the public policies and national employment rate over the acculturation strategies available to non-dominant groups still need to be further explored. The field lacks more quantitative data to measure the social, economic, and human value of the integration strategies for both dominant and non-dominant cultures.

As for the Haitian refugee in Brazil, the social integration process can become complete when the meaning of work in the culture of origin finds its expression in the host community, through stable and dignified employment. In this situation, he calms the anxieties from the transition and opens himself to contact with the other, while celebrating his culture and strengthening family ties with those who had stayed in the country.

\section{ACKNOWLEDGEMENTS}

We would like to thank the anonymous reviewers for their constructive and useful feedback, the Coordination for the Improvement of Higher Education Personnel (CAPES), a foundation within the Ministry of Education in Brazil, for supporting the first author with a scholarship, and all the informants who participated in this study. 


\section{REFERENCES}

Abdala, V. (2018, abril 27). Taxa de desemprego sobe para 13,1\%, diz pesquisa do IBGE. Agência Brasil. Retrieved from http://agenciabrasil.ebc.com.br/economia/noticia/2018-04/ taxa-de-desemprego-sobe-para-131-diz-pesquisa-do-ibge/

Alencar, A., \& Deuze, M. (2017). News for assimilation or integration? Examining the functions of news in shaping acculturation experiences of immigrants in the Netherlands and Spain. European Journal of Communication, 32(2), 1-16.

Audebert, C. (2017). The recent geodynamics of Haitian migration in the Americas : refugees or economic migrants? Revista Brasileira de Estudos de População, 34(1), 55-71.

Aycan, Z., \& Berry, J. W. (1996). Impact of Employment-Related Experiences on Immigrants' Psychological Weil-Being and Adaptation to Canada. Canadian Journal of Behavioural Science, 28(3), 240-251.

Bardin, L. (2008). Análise de Conteúdo (5a ed.). Lisboa, Portugal: Edições 70.

Berry, J. W. (1997). Immigration, Acculturation, and Adaptation. Applied Psychology: An international review, 46(1), 5-68.

Black, J. S., Mendenhall, M., \& Oddou, G. (1991). Toward a comprehensive model of international adjustment: an integration of multiple theoretical perspectives. The Academy of Management Review, 16(2), 291-317.

Cavalcanti, L., Oliveira, A. T., \& Araujo, D. (2016). A inserção dos imigrantes no mercado de trabalho brasileiro. Relatório Anual 2016. Brasília, DF: OBMigra. Retrieved from https://portaldeimigracao. mj.gov.br/images/dados_anuais/RelatorioCompleto_v8_0512_ pagespelhada_comcapa.pdf

Cavalcanti, L., Oliveira, T., \& Macedo, M. (2019). Imigração e Refúgio no Brasil. Relatório Anual 2019. Brasília, DF: OBMigra. Retrieved from https://portaldeimigracao.mj.gov.br/images/relatorio-anual/ RELAT\%C3\%93RIO\%20ANUAL\%20OBMigra\%202019.pdf

Cavalcanti, L., Tonhati, T., Dutra, D., \& Oliveira, M. (2017). A imigração haitiana no Brasil: características sócio-demográficas e laborais na região sul e no Distrito Federal. Brasília, DF: OBMigra. Retrieved from https://portaldeimigracao.mj.gov.br/images/publicacoes-obmigra/ Livro_V3_sumario_atualizado.pdf

Creswell, J. W. (2010). Projeto de pesquisa: métodos qualitativo, quantitativo e misto (3a. ed.). Porto Alegre, RS: Artmed.
Cruz, E. P., \& Falcão, R. P. Q. (2016). A bibliometric review of Immigrant and Ethnic Entrepreneurship. Review of International Business, 11(3), 78-94.

Dhudwar, A. (2004). Towards a Refugee Employment Strategy. Industrial Law Journal, 33(3), 286-291.

Eisnecker, P., \& Schacht, D. (2016). Half of the refugees in Germany found their first job through social contacts. DIW Economic Bulletin, 34, 414-422.

Krishnan, A., \& Berry, J. W. (1992). Acculturative Stress and Acculturation A ttitudes Among Indian Immigran ts to the United Sta tes. Psychology and Developing Societies, 4(2), 187-212.

Ministério da Justiça. (2018). Refúgio em números (3a ed.). Brasília, DF: Author. Retrieved from https://www.justica.gov.br/seus-direitos/ refugio/anexos/refasgio-em-nasmeros_1104.pdf/

Ministério da Justiça e Segurança Pública. (2019). Refúgio em Números (4a ed.). Brasília, DF: Author. Retrieved from https://www.justica. gov.br/seus-direitos/refugio/anexos/RefgioemNmeros_2018.pdf

Pachi, P. (2019). A precarização na base da mundialização contemporânea: a imigração haitiana na metrópole de São Paulo (Masther Thesis). Universidade de São Paulo, São Paulo, SP.

Peres, R. (2015). De norte a sul: imigração haitiana no Brasil. Diagnóstico de Pesquisa de Campo. Campinas, SP: NEPPO/UNICAMP.

Phillimore, J. (2011). Refugees, Acculturation Strategies, Stress and Integration. Journal of Social Policy, 40(3), 575-593.

Pongnon, V. N. (2016). Formação profissional e projeto de vida: a inserção dos imigrantes Haitianos e Cabo Verdianos no mercado de trabalho em Brasília. Universitas: Relações Internacionais, 14(1), 15-30.

Redfield, R., Linton, R., \& Herskovits, M. J. (1936). Memorandum for the study of acculturation. American Anthropologist, 38, 149-152.

Sam, D. L., \& Berry, J. W. (1995). Acculturative stress among young immigrants in Norway. Scandinavian Journal of Psychology, 36, 10-24.

Schmitz, P. (1992). Acculturation styles and health. In S. Iwawaki, Y. Kashima, \& K. Hung (Eds.), Innovations in cross-cultural psychology. Amsterdam, The Netherlands: Swets \& Zeitlinger.

Taras, V., Rowney, J., \& Steel, P. (2013). Work-related acculturation : change in individual work-related cultural values following immigration. The International Journal of Human Resource Management, 24(1), 130-151.

Eduardo Estellita de Oliveira Santos

ORCID: https://orcid.org/0000-0002-8936-8033

M.Sc. in Business Administration from the Mackenzie Presbyterian University. E-mail: eduardo.estellita@hotmail.com

Darcy Mitiko Mori Hanashiro

ORCID: https://orcid.org/0000-0003-2305-4186

Ph.D. in Business Administration from the University of Sao Paulo; Full Professor in the Graduate Program in Business Administration at Mackenzie

Presbyterian University. E-mail: darcyhanashiro@gmail.com 